\title{
Apoptosis of Murine Hepatocytes Induced by High Doses of Galactosamine
}

\author{
Shigeki TSUTSUI, Kensuke HIRASAWA, Makio TAKEDA, Shin-ichi ITAGAKI, Seiji KAWAMURA, Ken MAEDA ${ }^{1)}$, \\ Takeshi MIKAMI ${ }^{1)}$, and Kunio DOI \\ Departments of Biomedical Science and ${ }^{1}$ Veterinary Microbiology, Faculty of Agriculture, The University of Tokyo, 1-1-1 Yayoi, \\ Bunkyo, Tokyo 113, Japan
}

(Received 6 March 1997/Accepted 15 May 1997)

ABSTRACT. Apoptosis induced by high doses of Galactosamine (GalN) was investigated in mice hepatocytes in vivo. In mice intraperitoneally (ip) treated with GalN $3 \mathrm{~g} / \mathrm{kg}$, the terminal deoxynucleotidyl transferase-mediated dUTP nick end labeling (TUNEL)positive cells were first observed at $6 \mathrm{hr}$ postadministration (PA). Both acidophilic bodies in hematoxylin and eosin (HE)-stained sections and TUNEL-positive cells were markedly found at $24 \mathrm{hr}$ PA. At $48 \mathrm{hr}$ PA, cellular degeneration and necrosis of hepatocytes were prominently observed, and TUNEL-positive cells were scarcely found. In the mice ip treated with GalN $1.5 \mathrm{~g} / \mathrm{kg}$, the lesion was milder than that in those treated with GalN $3 \mathrm{~g} / \mathrm{kg}$. Acidophilic bodies and TUNEL-positive cells were scarcely found at $24 \mathrm{hr}$ PA, whereas they were markedly seen at $48 \mathrm{hr}$ PA. In addition, a ladder-like DNA fragmentation pattern by agarose gel electrophoresis was observed most remarkably at $24 \mathrm{hr}$ PA with GalN $3 \mathrm{~g} / \mathrm{kg}$ and at $48 \mathrm{hr}$ PA with GalN $1.5 \mathrm{~g} / \mathrm{kg}$, and less distinctly at $48 \mathrm{hr}$ PA with GalN $3 \mathrm{~g} / \mathrm{kg}$. On the other hand, sGOT and sGPT activities increased prominently at $48 \mathrm{hr}$ PA with GalN $3 \mathrm{~g} / \mathrm{kg}$. These results suggest that the cell death induced by high dose of GalN may be caused by apoptosis, and subsequently by necrosis in vivo. — KEY wORDs: apoptosis, galactosamine, hepatotoxicity, liver, mouse.

D-galactosamine (GalN) has been known to induce liver injury by depletion of uracil nucleotides and to produce acidophilic single cell necrosis of hepatocytes. In rats, a single injection of GalN induced the acute liver disease, that morphologically resembled drug-induced hepatitis in human beings, giving an extremely interesting experimental model [3]. From the results of some preliminary examinations of GalN-intoxication in mice, we had a strong impression that at least a part of such acidophilic single cell necrosis of hepatocytes might be apoptosis. As the first step to confirm this point, we carried out the examination of in vitro hepatotoxicity of GalN and clarified that GalN could induce apoptotic death of hepatocyte at least in vitro [27].

It is well known that apoptosis plays a critical role in cell death during the processes of maturation and/or development of the immune and nervous systems [5, 12]. It is also said that apoptosis is involved in kinetics of tumor cells [14, 22]. Recently it has been reported that some kinds of cytotoxic chemicals and toxins could also induce apoptosis mainly in component cells of lymphoid organs [1, 13] or cell lines [24]. However, there are a few reports of chemical-induced apoptosis in parenchymal cells of the liver and kidney, which are the main target organs of cytotoxic chemicals $[19,20]$. In the present study, to clarify the relationship between the GalN-induced hepatotoxicity and apoptosis in vivo, we investigated whether high doses of GalN could induce apoptosis in mouse hepatocytes and compared with the levels of serum glutamate oxaloacetate transaminase (sGOT) and serum glutamate pyruvate transaminase (sGPT), an indicator of hepatotoxicity.

\section{MATERIALS AND METHODS}

Animals: Eight-week-old C57BL/6N Crj male mice
(Charles River Japan Inc., Atsugi, Japan) were maintained under controlled conditions (temperature, $22 \pm 2{ }^{\circ} \mathrm{C}$; humidity, $55 \pm 5 \%$; 12-hr light and dark cycle) and fed a commercial pelleted diet, MF (Oriental Yeast Co. Ltd., Tokyo), and water ad libitum.

GalN treatment: D-GalN-HCl (Sigma Chemical Co., St. Louis, MO) was dissolved at a concentration of $0.15 \mathrm{~g} / \mathrm{m} l$ in physiologic saline with $\mathrm{pH}$ adjusted to 6.8 with $\mathrm{NaOH}$ and administered intraperitoneally (ip) at a dose of 1.5 or 3 $\mathrm{g} / \mathrm{kg}$ to animals in each group. After administration, 5 animals each were euthanatized at 3, 6, 12, 24, 36 and $48 \mathrm{hr}$ $\mathrm{PA}$, for collection of blood and liver samples in time course studies. Five animals received physiologic saline alone as control animals and were killed at $48 \mathrm{hr}$. Portions of the removed liver and separated serum were immediately frozen, and stored at $-85^{\circ} \mathrm{C}$ until use. For electron microscopy, the liver tissue was fixed with modified Karnovsky's solution (2\% paraformaldehyde and $2.5 \%$ glutaraldehyde in $0.05 \%$ phosphate buffer, $\mathrm{pH} 7.4$ ), postfixed with $1 \%$ osmium tetroxide in the same buffer, and embedded in epoxy resin, Quetol-812 (Nissin EM, Tokyo). Ultrathin sections were stained with uranyl acetate and lead citrate and examined under a transmission electron microscopy, 1200 EX (JEOL Co., Ltd., Tokyo). The rest of the liver was fixed in $10 \%$ neutral buffered formalin for light microscopy. Paraffin sections were cut and stained with hematoxylin and eosin (HE) or the terminal deoxynucleotidyl transferase-mediated dUTP nick end labeling (TUNEL) method for specific staining of DNA fragmentation and apoptotic bodies, using Apoptag kit (Oncor, Gaithersburg, MD). Staining by the TUNEL method was carried out according to the manufacturer's protocol.

Evaluation of hepatotoxicity: Blood samples obtained from each animal were analyzed by an autoanalyzer, 
Monarch (Instrumentation Laboratory, U.S.A.). Cytotoxicity by GalN was evaluated by the level of sGOT and SGPT activities. The data were expressed as the mean $\pm \mathrm{SD}$ of 5 mice each. Statistical significances were determined using Student's $t$-test. A $p$ value $<0.05$ was accepted as significant.

DNA isolation and agarose gel electrophoresis: The frozen liver was hashed into small pieces. Then tissue was lysed by adding DNA extraction buffer $(10 \mathrm{mM}$ Tris- $\mathrm{HCl}$, $150 \mathrm{mM} \mathrm{NaCl}, 10 \mathrm{mM}$ EDTA, 0.1\% SDS, pH 8.0) and incubated at $37^{\circ} \mathrm{C}$ for $1 \mathrm{hr}$ followed by incubation more than $2 \mathrm{hr}$ at $55^{\circ} \mathrm{C}$ in the presence of $100 \mu \mathrm{g} / \mathrm{ml}$ of proteinase $\mathrm{K}$ to get cell lysate. DNA was extracted from the lysate with equal volumes of phenol, phenol:chloroform (1:1), and diethyl ether and precipitated in $67 \%$ ethanol at $-20^{\circ} \mathrm{C}$ overnight. The precipitates were digested with RNase A $\left(10 \mu \mathrm{g} / \mathrm{ml}, 1 \mathrm{hr}\right.$ at $\left.37^{\circ} \mathrm{C}\right)$. DNA samples $(<30 \mu \mathrm{g})$ were subjected to electrophoresis on $1.8 \%$ agarose gel (FMC BIO Products, Rockland, ME, U.S.A.) and visualized by UV fluorescence after staining with ethidium bromide $(6 \mu \mathrm{g} / \mathrm{m} l)$ in order to detect qualitative damage to genomic DNA.

\section{RESULTS}

1. Morphological changes on GalN-induced hepatotoxicity: Under light microscopy, the control liver showed no apparent changes and TUNEL-positive cells were scarcely observed (Figs. 1a, b). In the group treated with GalN $3 \mathrm{~g} / \mathrm{kg}$, TUNEL-positive cells were first observed at 6 hr PA but they exhibited normal features by HE-staining. At 12 hr PA, a few densely eosinophilic shrunken dead cells (acidophilic bodies) with atrophic cytoplasm were observed in HE-stained sections (Fig. 1c), and these acidophilic bodies were TUNEL-positive (Fig. 1d). At 24 hr PA, the acidophilic bodies and TUNEL-positive cells increased in number markedly (Figs. 1e, f). Another type of TUNEL-positive cells, which had nuclei with chromatin margination and normal cytoplasm, were also observed. At $48 \mathrm{hr}$ PA, cellular degeneration and necrosis of hepatocytes were markedly observed (Fig. 1g), and TUNEL-positive cells were scarcely found (Fig. 1h). In the group treated with GalN $1.5 \mathrm{~g} / \mathrm{kg}$, the lesions were milder than those in the group treated with GalN $3 \mathrm{~g} / \mathrm{kg}$. Acidophilic bodies and TUNEL-positive cells were scarcely found at $24 \mathrm{hr}$ PA (Fig. 2a), whereas they were markedly seen at $48 \mathrm{hr}$ PA (Fig. 2b).

In the electron microscopic examinations, typical apoptotic bodies with nuclear chromatin condensation were detected at $24 \mathrm{hr}$ PA of GalN $3 \mathrm{~g} / \mathrm{kg}$ (Fig. 3). Unfortunately, it was impossible to find typical apoptotic bodies in mice treated with GalN $1.5 \mathrm{~g} / \mathrm{kg}$, because frequency of apoptosis was lower than that in mice treated with GalN $3 \mathrm{~g} / \mathrm{kg}$

2. Findings of agarose gel electrophoresis: As shown in Fig. 4, a ladder-like DNA fragmentation pattern as multiples of 180-200 bp was detected remarkably at $48 \mathrm{hr}$ PA in 1.5 $\mathrm{g} / \mathrm{kg}$ GalN-treated group and at $24 \mathrm{hr}$ PA in $3 \mathrm{~g} / \mathrm{kg} \mathrm{GalN-}$ treated group, respectively. Such a fragmentation pattern, however, had a tendency to disappear at $48 \mathrm{hr}$ PA in $3 \mathrm{~g} / \mathrm{kg}$ GalN-treated group. In control group, the fragmentation pattern of DNA could not be detected.

3. Changes of serum aminotransferases: As shown in Table 1 , the levels of sGOT and sGPT rose gradually up to $12 \mathrm{hr}$ PA in both 1.5 and $3 \mathrm{~g} / \mathrm{kg} \mathrm{GalN}$-treated groups, and the levels reached about 2.5- (GOT) and 4.3-fold (GPT) of the control value. Then, in $3 \mathrm{~g} / \mathrm{kg}$ GalN-treated group, the sGOT and sGPT activities increased markedly and were about 80 - and 230 -fold of the control value at $48 \mathrm{hr}$ PA, respectively. On the other hand, increase in activities of the sGOT and sGPT were slight in $1.5 \mathrm{~g} / \mathrm{kg} \mathrm{GalN}$-treated group up to $48 \mathrm{hr}$ PA.

\section{DISCUSSION}

Apoptosis in the liver has been reported to be induced mainly by cytokines such as TGF- $\beta 1[4,16]$ and TNF- $\alpha$ [10] and through Fas antigen $[15,17]$. As mentioned in Introduction, there are a few reports of apoptosis of hepatocytes induced by drugs and chemicals such as dimethylnitrosamine, a carcinogen [19], vinblastine and colchicine, microtubule antagonists [26], and acetaminophen, an analgesic [20, 25]. In addition, it has been also reported that agents such as dimethylnitrosamine, 1,1- dichloroethylene, heliotrine and thioacetamide can induce both apoptosis and necrosis of hepatocytes in vivo $[6,8,9,18,21]$. In the previous study, we reported that GalN also could induce apoptotic death in the cultured hepatocytes from $\mathrm{C} 57 \mathrm{BL} / 6 \mathrm{~N}$ mice, followed by necrotic death [27].

In this study, by TUNEL method, fragmented DNA could be detected in acidophilic bodies after treatment with $1.5 \mathrm{~g} /$ $\mathrm{kg}$ and $3 \mathrm{~g} / \mathrm{kg}$ of GalN. Furthermore, a ladder-like fragmentation pattern was clearly detected by agarose gel electrophoresis when TUNEL-positive cells were prominently observed. Thus, it can be concluded that acidophilic bodies observed in the murine liver after treatment with high dose of GalN are apoptotic bodies, and that most of the cell death is caused by apoptosis on the early stage. Searle et al. [23] have suggested a possibility that acidophilic bodies observed in many liver diseases such as viral hepatitis were caused by apoptotic process, and they stressed the biological significance of this phenomenon.

DNA fragmentation was most remarkably seen at $48 \mathrm{hr}$ PA with GalN $1.5 \mathrm{~g} / \mathrm{kg}$ and at $24 \mathrm{hr}$ PA with GalN $3 \mathrm{~g} / \mathrm{kg}$, and less distinctly at $48 \mathrm{hr}$ PA with GalN $3 \mathrm{~g} / \mathrm{kg}$. On the other hand, sGOT and sGPT levels increased prominently only at $48 \mathrm{hr}$ PA with GalN $3 \mathrm{~g} / \mathrm{kg}$. Namely, DNA fragmentation preceded the prominent increase in SGOT and sGPT activities, the indicators of hepatotoxicity. Moreover, most degenerative cells were negative for TUNEL method. At this point, activities of sGOT and sGPT reached the maximum level. Our previous examinations with cultured mouse hepatocytes exposed to GalN revealed that the typical ultrastructural feature of necrosis was observed when the intracellular enzyme leaked to medium [27]. Differentiation 


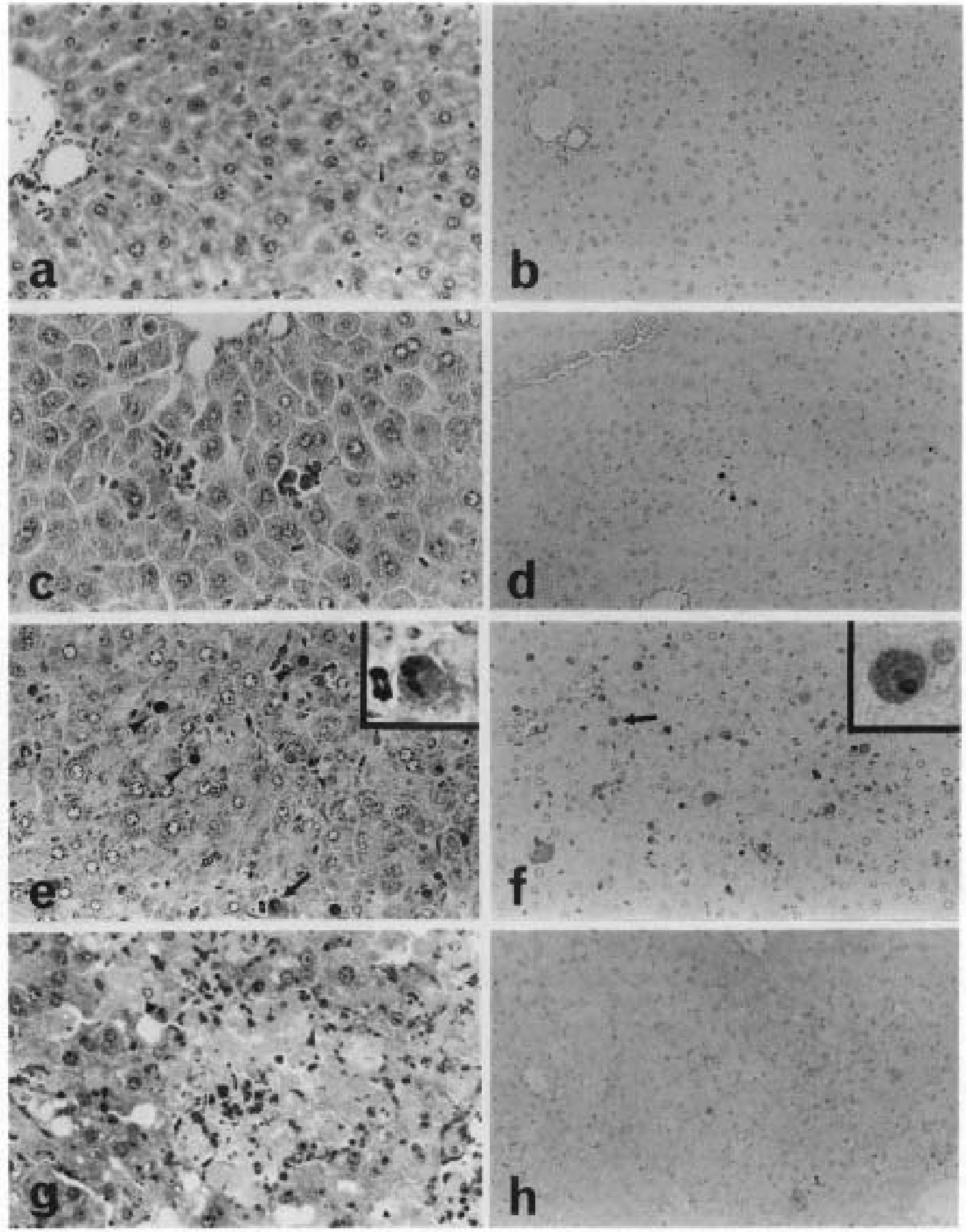

Fig. 1. H-E (a, c, e and g) and TUNEL (b, d, f and h) staining of murine liver sections in control and $3 \mathrm{~g} / \mathrm{kg}$ GalN-treated group $(H-E: \times 330$, TUNEL: $\times 165)$. (a) and (b) are these of control group: These are no apparent changes and TUNEL-positive cells are scarcely observed. (c) and (d) are these of $12 \mathrm{hr}$ PA with GalN: A few acidophilic bodies are observed, and they are positive with TUNEL method. (e) and (f) $24 \mathrm{hr}$ PA: Acidophilic bodies, indicated by an arrow and arrowheads in (e), and TUNEL-positive cells are markedly increased in number. Insets: Higher magnification of an acidophilic body and a TUNELpositive cell indicated by an arrow in (e) and (f), respectively $(\times 1,100)$. (g) and (h) $48 \mathrm{hr}$ PA: Cellular degeneration and necrosis of hepatocytes are markedly observed and TUNEL-positive cells are scarcely found. 


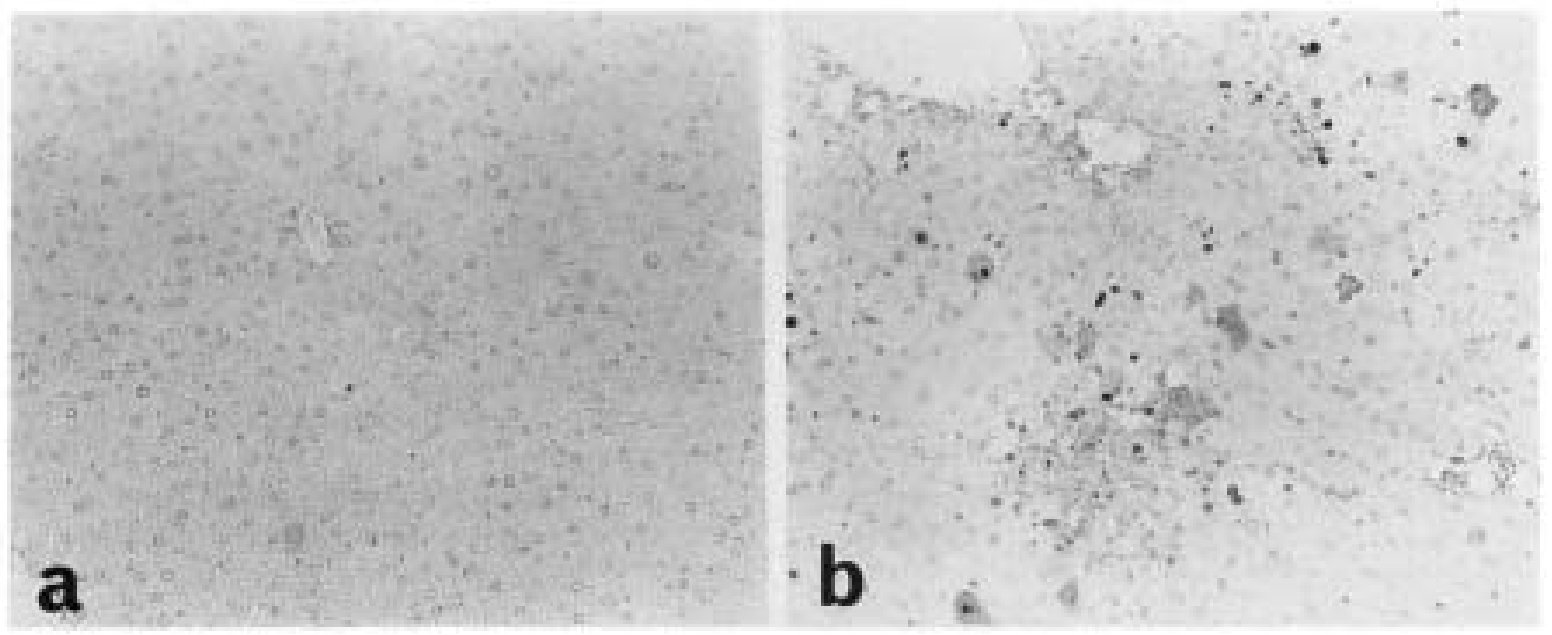

Fig. 2. TUNEL staining of murine liver sections in $1.5 \mathrm{~g} / \mathrm{kg}$ GalN-treated group $(\times 165)$. TUNEL-positive cells are scarcely found at $24 \mathrm{hr}$ PA (a), and then markedly at $48 \mathrm{hr}$ PA (b).

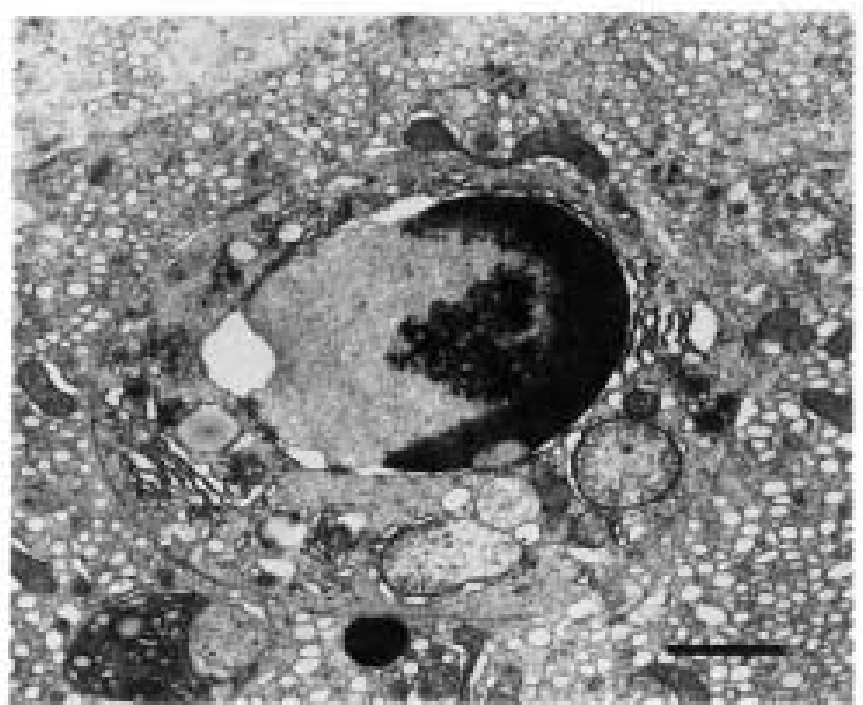

Fig. 3. Electron micrograph of the liver at $24 \mathrm{hr}$ after treatment with 3 $\mathrm{g} / \mathrm{kg}$ GalN. A typical apoptotic body with nuclear chromatin condensation. $\mathrm{Bar}=2 \mu \mathrm{m}$.

between chemically induced apoptosis and necrosis is considerably difficult, but, as Corcoran et al. [2] stated, morphology at the cell and ultrastructural levels remains the golden standard for the differentiation between apoptosis and necrosis. From these viewpoints, cell death observed mainly at $48 \mathrm{hr}$ PA was considered to be necrosis. Therefore, it can be considered that cell death induced by high dose of GalN may be caused by apoptosis, and subsequently by necrosis in vivo as well as in vitro.

Apoptosis and/or necrosis may be induced by different dosages of a xenobiotic or a different stages of lesion development $[6,7,9,18,21]$. However, as Levin [11] pointed out, it is still obscure whether the 2 faces of cell death reflect a continuum caused by a single agent or not. The present system in vivo may be useful to clarify this

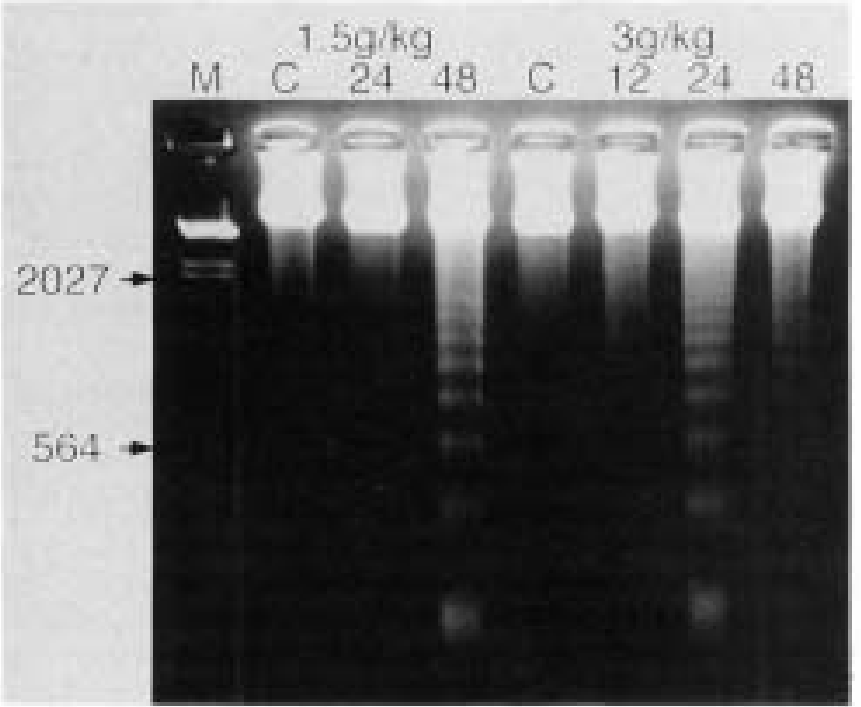

ig. 4. Qualitative evaluation of GalN-induced damage to murine liver DNA. The electrophoretogram demonstrates concentrationand time-dependent damage to genomic DNA. M, molecular size makers from HindIII digested $\lambda$ DNA; C, control; 12 , GalNtreatment for $12 \mathrm{hr}$ PA; 24, GalN-treatment for $24 \mathrm{hr}$ PA; 48, GalNtreatment for $48 \mathrm{hr} P A ; 1.5 \mathrm{~g} / \mathrm{kg}, 1.5 \mathrm{~g} / \mathrm{kg}$ GalN-treated group; $3 \mathrm{~g} /$ $\mathrm{kg}, 3 \mathrm{~g} / \mathrm{kg}$ GalN-treated group.

point as well as in vitro system.

Although the mechanism of GalN-induced apoptosis in liver is still obscure, changes in kinetics of cellular $\mathrm{Ca}^{2+}$ seem to play one of the most important role. Because our preliminary examinations using in vitro and in vivo system clearly revealed that the pretreatment with chlorpromazine, a $\mathrm{Ca}^{2+}$-calmodulin antagonist or with verapamil, a $\mathrm{Ca}^{2+}$ channel blocker, inhibited the development of DNA-fragmentation and the appearance of apoptotic bodies. The data will be published elsewhere. The investigations of the relationship between GalN-induced apoptosis and 
Table 1. Changes of sGOT and sGPT levels of GalN-treated mice

\begin{tabular}{rlcccc}
\hline \multirow{2}{*}{ Time } & \multicolumn{2}{c}{ sGOT $(\mathrm{U} / \mathrm{L})$} & & \multicolumn{2}{c}{ sGPT $(\mathrm{U} / \mathrm{L})$} \\
\cline { 2 - 3 } \cline { 5 - 6 } & $1.5 \mathrm{~g} / \mathrm{kg} \mathrm{GalN}$ & $3 \mathrm{~g} / \mathrm{kg} \mathrm{GalN}$ & & $1.5 \mathrm{~g} / \mathrm{kg} \mathrm{GalN}$ & $3 \mathrm{~g} / \mathrm{kg} \mathrm{GalN}$ \\
\hline \multirow{2}{*}{ Control } & $85.75 \pm 36.80$ & - & & $37.25 \pm 10.05$ & - \\
3 & $132.7 \pm 35.91$ & $125.5 \pm 64.14$ & & $49.0 \pm 4.00^{*}$ & $46.8 \pm 3.78$ \\
6 & $127.0 \pm 32.70$ & $170.5 \pm 16.44^{* *}$ & & $53.3 \pm 4.16^{*}$ & $52.0 \pm 2.00^{*}$ \\
12 & $250.5 \pm 124.1 *$ & $211.8 \pm 15.78^{* * *}$ & & $161.3 \pm 109.3^{*}$ & $161.3 \pm 34.67^{* * *}$ \\
24 & $228.7 \pm 143.3$ & $513.3 \pm 412.4^{*}$ & & $288.7 \pm 236.5^{*}$ & $554.3 \pm 402.0^{*}$ \\
48 & $210.3 \pm 31.13^{* * *}$ & $6904.3 \pm 2684.7^{* * *}$ & $245.3 \pm 61.79^{* * *}$ & $8999.3 \pm 1675.9^{* * *}$
\end{tabular}

Values are means $\pm \mathrm{SD}$ of five animals. ${ }^{*} p<0.05, * * p<0.01, * * * p<0.001 v s$. control, by Student's $t$ test.

depleting effect of GalN on uracil nucleotides are now in progress.

ACKNOWLEDGMENT. This work was supported in part by Grant-in-Aid (No. 0756139) from the Ministry of Education, Science and Culture, Japan.

\section{REFERENCES}

1. Aw, T. Y., Nicotera, P., Manzo, L., and Orrenius, S. 1990. Tributylin stimulates apoptosis in rat thymocytes. Arch. Biochem. Biophys. 283: 46-50.

2. Corcoran, G. B., Fix, L., Jones, D. P., Moslen, M. T., Nicotera, P., Oberhammer, F. A., and Buttyan, R. 1994. Apoptosis: molecular control point in toxicity. Toxicol. Appl. Pharmacol. 128: $169-181$.

3. Decker, K. and Keppler, D. 1972. Galactosamine induced liver injury. pp. 183-199. In: Progress in Liver Disease, vol. IV (Hopper, H. and Schaffner, F. eds.), Grune and Stratton, New York.

4. Fukuda, K., Kojiro, M., and Chiu, J. F. 1993. Induction of apoptosis by transforming growth factor- $\beta 1$ in the rat hepatoma cell line McA-RH7777: a possible association with tissue transglutaminase expression. Hepatology 18: 945-953.

5. Gougeon, M. L. and Montagnier, L. 1993. Apoptosis in AIDS. Science 260: 1269-1270.

6. Hirata, K., Ogata, I., Ohta, Y., and Fujiwara, K. 1989. Hepatic sinusoidal cell destruction in the development of intravascular coagulation in acute liver failure of rat. J. Pathol. 158: $157-165$.

7. Hockenberry, D. 1995. Defining apoptosis. Am. J. Pathol. 146: $16-19$.

8. Kerr, J. F. R. 1969. An electron-microscope study of liver cell necrosis due to heliotrine. J. Pathol. 97: 557-561.

9. Ledda-Columbano, G. M., Coni, P., Curto, M., Giacomini, L., Faa, G., Oliverio, S., Piacentini, M., and Columbano, A. 1991. Induction of two different modes of cell death, apoptosis and necrosis, in rat liver after a single dose of thioacetamide. Am. J. Pathol. 139: 1099-1109.

10. Leist, M., Gantner, F., Bohlinger, I., Germann, P. G., Tiegs, G., and Wendel, A. 1994. Murine hepatocyte apoptosis induced in vitro and in vivo by TNF- $\alpha$ requires transcriptional arrest. J. Immunol. 153: 1778-1788.

11. Levin, S. 1995. A toxicologic pathologist's view of apoptosis or I used to call it necrosis, but now I'm singing the apoptosis blues. Toxicol. Pathol. 23: 533-539.

12. Martin, D. P., Ito, A., Horigome, K., Lampe, P. A., and
Johnson, E. M. Jr. 1993. Biochemical characterization of programmed cell death in NGF-deprived sympathetic neurons. $J$. Neurobiol. 23: 1205-1220.

13. McConkey, D.J., Hartzell, P., Duddy, S.K., Hakansson, H., and Orrenius, S. 1988. 2,3,7,8-Tetrachlorodibenzo-p-dioxin kills immature thymocytes by $\mathrm{Ca}^{2+}$-Mediated mediated endonuclease activation. Science 242: 256-259.

14. Moor, J. V. 1987. Death of cells and necrosis of tumors. pp. 295-325 In: Perspectives in Mammalian Cell Death (Potten, C. S. ed.), Oxford University Press, Oxford.

15. Ni, R., Tomita, Y., Matsuda, K., Ichihara, A., Ishimura, K., Ogasawara, J., and Nagata, S. 1994. Fas-mediated apoptosis in primary cultured mouse hepatocytes. Exp. Cell Res. 215: 332-337.

16. Oberhammer, F., Bursch, W., Tiefenbacher, R., Froschl, G., Pavelka, M., Purchio, T., and Schulte-Hermann, R. 1993. Apoptosis is induced by transforming growth factor- $\beta 1$ within 5 hours in regressing liver without significant fragmentation of the DNA. Hepatology 18: 1238-1246.

17. Ogasawara, J., Watanabe-Fukunaga, R., Adachi, M., Matsuzawa, A., Kasugai, T., Kitamura, Y., Itoh, N., Suda, T., and Nagata, S. 1993. Lethal effect of the anti-Fas antibody in mice. Nature (Lond.) 364: 806-809.

18. Pritchard, D. J. and Butler, W. H. 1989. Apoptosis-the mechanism of cell death in dimethylnitrosamine-induced hepatotoxicity. J. Pathol. 158: 253-260.

19. Ray, S. D., Sorge, C. L., Kamendulis, L. M., and Corcoran, G. B. 1992. $\mathrm{Ca}^{++}$-activated DNA fragmentation and dimethylnitrosamine-induced hepatic necrosis: effects of $\mathrm{Ca}^{++}$-endonuclease and poly (ADP-ribose) polymerase inhibitors in mice. J. Pharm. Exp. Therapeutics 263: 387-394.

20. Ray, S. D., Kamendulis, L. M., Gurule, M. W., Yorkin, R. D., and Corcoran, G. B. 1993. $\mathrm{Ca}^{2+}$-antagonists inhibit DNA fragmentation and toxic cell death induced by acetaminophen. FASEB J. 7: 453-463.

21. Reynolds, E. S., Kanz, M. F., Chieco, P., and Moslen, M. T. 1984. 1,1-Dichloro ethylene: an apoptotic hepatotoxin? Environ. Health Perspect. 57: 313-320.

22. Sarraf, C. E. and Bowen, I. D. 1988. Proportions of mitotic and apoptotic cells in a range of untreated experimental tumors. Cell Tissue Kinet. 21: 45-49.

23. Searle, J., Harmon, B. V., Bishop, C. J., and Kerr, J. F. R. 1987. The significance of cell death by apoptosis in hepatobiliary disease. J. Gastroenterol. Hepatol. 2: 77-96.

24. Seegers, J. C., Böhmer, L. H., Kruger, M. C., Lottering, ML., and de Kock, M. 1994. A comparative study of Ochratoxin A-induced apoptosis in hamster kidney and HeLa cells. Toxicol. Appl. Pharmacol. 129: 1-11. 
25. Shen, W., Kamendulis, L. M., Ray, S. D., and Corcoran, G. B. 1991. Acetaminophen-induced induced cytotoxicity in cultured mouse hepatocytes: correlation of nuclear $\mathrm{Ca}^{2+}$ accumulation and early DNA fragmentation with cell death. Toxicol. Appl. Pharmacol. 111: 242-254.

26. Tsukidate, K., Yamamoto, K., Snyder, J. W., and Farber, J. L. 1993. Microtubule antagonists activate programmed cell death (apoptosis) in cultured rat hepatocytes. Am. J. Pathol. 143: 918-925.

27. Tsutsui, S., Hirasawa, K., Takeda, M., Itagaki, S., Kawamura, S., Maeda, K., Mikami, T., and Doi, K. 1997. Galactosamineinduced apoptosis in the primary mouse hepatocyte cultures. Exp. Toxicol. Pathol. 48: (in press). 